\title{
Essential Oils and Latices as Novel Antiviral Agent Against Potato Leaf Roll Virus and Analysis of Their Phytochemical Constituents Responsible for Antiviral Activity
}

\author{
Sehrish Iftikhar ${ }^{1}$, Ahmad Ali Shahid ${ }^{1}$, Shabnam Javed ${ }^{1}$, Idrees Ahmad Nasir ${ }^{2}$, Bushra Tabassum ${ }^{2} \&$ \\ M. Saleem Haider ${ }^{1}$ \\ ${ }^{1}$ Institute of Agricultural Sciences, University of the Punjab, Lahore, Pakistan \\ ${ }^{2}$ Centre of Excellence in Molecular Biology, University of the Punjab, Lahore, Pakistan \\ Correspondence: Ahmad Ali Shahid, Institute of Agricultural Sciences, University of the Punjab, Lahore, Pakistan. \\ Tel: 92-42-9923-1846. E mail: ahmadali.shahid@gmail.com
}

\author{
Received: April 27, 2013 Accepted: May 27, 2013 Online Published: June 15, 2013 \\ doi:10.5539/jas.v5n7p167 URL: http://dx.doi.org/10.5539/jas.v5n7p167
}

\begin{abstract}
The present work was aimed to limit the practice of using pesticides in the managing program of the potato leaf roll disease on potato plants as the misuse of some pesticides had caused severe problems. The study was focused to find compounds nontoxic and safe for the biome. The antiviral activity of essential oils and latices tapped from different plants was investigated against potato leaf roll virus (PLRV). Essential oils from Eucalyptus citriodora leaves, Clove buds, and Fennel seeds were extracted. Latex of Aloe vera, Calotropis procera and Ficus elastic were collected. Essential oil and latex spray solutions were prepared at 5 and $10 \%$ concentration. All the sprayings were done at 7 days interval. Inhibition of viral replication was monitored by amplification of PLRV capsid protein gene and mRNA expression using RT-PCR technique. Results depicted inhibitory potential of all the tested essential oils and latices against PLRV infestation and also the effect was found concentration dependent. Our data showed that Aloe vera latex and clove essential oil caused maximum inhibition viral mRNA at 10\% concentration. Qualitatively analyzed Tannin, Phlobactanins, Saponin, Flavonoids, Sterols and Terpens from essential oils and latices gave positive results in most of the oils and lesser content in plant latices. In the GC-MS analysis, high contents of some bioactive phytochemical compounds identified were Eugenol in Clove buds, Eucalyptol, D-Limonene and L-Limonene both in Eucalyptus leaves and Fennel seed oils and Fenchone in Fennel seeds. As this research work illustrates, there is innumerable potential of plants essential oils/latex waiting to be evaluated and exploited against genetically and functionally diverse plant viruses.
\end{abstract}

Keywords: antiviral, essential oils, latex, potato leaf roll virus, phytochemistry, GC-MS

\section{Introduction}

Potato plants are susceptible to many viruses that caused heavy losses in the yield of both quality and quantity (Valkonen, 2007; Mansour et al., 2008). 27 viral diseases have been stated to infect potatoes, among these diseases, potato leaf roll virus (PLRV) and potato virus Y (PVY) are distributed globally and are the most destructive. These two viruses are most important economically in the potato crop. Potato leaf roll disease is caused by Potato Leaf Roll Virus (PLRV). Worldwide, Potato leaf roll disease is considered as one of the major viral diseases of potato but particularly overwhelming in countries like Pakistan with inadequate management and resources. External symptoms appear as upward rolling of the grown-up leaves. Entire plant is stunted with chlorosis. Internal symptoms on tubers include brown necrotic arches or streaks making a net like shape (Peters \& Jones, 1981; Marsh et al., 1998). Vascular tissues also become necrotic in infected tubers, rendering them unmarketable. Potato leaf roll disease can cause substantial fall in yield, which may increase up to 50\% (Hamm \& Hane, 1999; Mariano, 1989; Jayasingh, 1988). In Pakistan, potato crop losses were reported up to 83\% due to viruses (Mughal \& Khalid, 1985). Annual global yield loss due to potato leaf roll disease is 20 million tons according to an estimate (Wales, Platt, \& Cattlin, 2008). Tubers produced by the infected plants are small in size and are not desirable in market. The plants grown from infected tubers can cause yield loss of 33-50\%. 
Several conventional strategies to control virus infection have been explored but without much success. Some chemicals are used to control the disease caused by PLRV. The main obstacle to the development of effective chemotherapy is the nature of virus multiplication in the host cells (Yarmolinsky, Zaccai, Ben Shabat, Mills, \& Huleikel, 2009). In addition to that some viruses persist in a latent infection in the host (Hull, 2002). The protective pesticides are mainly used to control the potato diseases (Stevenson, Loria, Franc, \& Weingartner, 2001). These pesticides however do not always control the diseases and severe losses can still occur. Synthetic chemicals cause environmental pollution in many ways including ground water contamination, widespread killing of non-target organisms. Medicinal plants with a background of traditional usage having significant antimicrobial activity provide an alternative approach to control the diseases (Vlietinck \& Berghe, 1991). There is a necessity to ascertain new antiviral compounds of diverse chemical nature and novel mechanisms of action against novel and newly evolving contagious diseases. Crop yield can be increased by using synthetic pesticides and they also provide stable production of crop with good quality. However, pesticide-resistant pathogen strains have been developed due to augmented use of pesticides (Staub, 1991) and have resulted in accumulation of pesticide residues in the food chain beyond nontoxic limits (El-Nahhal, 2004). A better disease management program should with devised based on substitutes to synthetic pesticides. Plant-derived compounds should be considered amongst the numerous substitutes (Kishore \& Pande, 2004). Essential oils are one of the important groups of plant-derived compounds. They are a combination of different terpenoid compounds and their oxygenated derivatives (Wijesekara, Ratnatunga, \& Durbeck, 1997). Broad-spectrum antimicrobial activity of these oils has been acknowledged against many pathogens (Daferera, Ziogas, \& Polission, 2003; Pandey, Rai, \& Acharya, 2003).

An essential oil is a rigorous hydrophobic liquid comprising of volatile components extracted from plants. Essential oils are also known as ethereal oils, volatile oils or aetherolea. The name "essential" is derived from a distinctive scent, or essence that it carries. A commercial formulation of mint oil known as Funga-Stop is available to control soil borne pathogens. However, these essential oils need to be researched further before they become dominant in agriculture and horticulture. Since early times, plants and their essential oils are known to have variable degree of antimicrobial potential (Zaika, 1988; Beuchat \& Golden, 1989). Essential oils have been shown to have numerous antimicrobial i.e., antiviral, antifungal, antibacterial, antioxidant, and insecticidal properties (Ozcan \& Sagic, 2006; Cafarchia, De-Laurentis, Milillo, Losacco, \& Puccini, 2002; Vardar-Unlu et al., 2003; Kalemba \& Kunicka, 2003). The substances that have the ability to preclude pathogens and are less toxic to host cells can be considered for emerging antimicrobial drugs.

Latex is a biological fluid present in many plants. Approximately $6 \%$ of all vascular plant species are recognized as constructing laticifers. There has been a growing interest in laticifers and their metabolism, although there is still limited information available, the importance of these plant fluids has been increasingly recognized and revised (Hagel, Yeung, \& Facchini, 2008; Pickard, 2008). Nonetheless, few latex-producing plants have been studied in detail and many laticifer plants involved in toxic events or exhibiting pharmacological properties still deserve basic biological investigations. Latex is a fluid, frequently with a milky aspect, synthesized by specialized cells called laticifers. The biological significance of latex in plants is still poorly understood. In the light of accumulated published data, most authors hold the hypothesis of a defensive role of latices towards insects and phytopathogens. This belief is mainly supported by the phytochemical profile found in distinct latices (Konno et al., 2004; Taira, Ohdomari, Nakama, Shimoji, \& Ishihara, 2005; Farias et al., 2007). It is not only of physiological importance but also of botanic interest to understand the metabolic activities of latices and their implications in plant protection. Recent studies of latices have contributed to the understanding of the occurrence and structure of secondary metabolites naturally accumulated in laticifers (Elsasser et al., 2005; Mazoir, Benharref, Bailén, Reina, \& Gonzalez-Coloma, 2008).

Natural products are admirable substitute to synthetic pesticides as a means to reduce adverse influences to the environment and human health. Systemic acquired resistance (SAR) can be applied as an alternative to the traditional methods of plant protection. In many of recent approaches involving viral components, the induced resistance is very specific to a particular strain or group of viruses (Gholizadeh et al., 2004). Biological and chemical means are used to systematically induce the resistance in many plant species (Ryals, Uknes, \& Ward, 1994; Spletzer \& Enyedi, 1999). Toxic compounds can applied to activate host defense mechanisms as a potential management approach (Durrant \& Dong, 2004). Thus, on the one hand, the biodegradable highly selective pesticides have to be searched to resolve the problem of extended toxicity and, on the other hand, they should be environmental friendly.

Present studies were aimed for the essential oil extraction from Eucalytpus citriodora, Foeniculum vulgare and Syzygium aromaticum by hydro-distillation technique and plant latices isolation from Aloe vera, Calotropis 
procera and Ficus elastic by centrifugation and to assess the antiviral activity of selected essential oils and plant latices against potato leaf roll virus (PLRV) in vivo. Phytochemical investigation of essential oils and latices for qualitative detection of bioactive compounds e.g. alkaloids, tannins, sterols, phenols and flavonoids was done along with GC/MS analysis of essential oils to detect the active components.

\section{Methodology}

\subsection{Collection \& Identification of Plants}

The seeds of Foeniculum vulgare (Fennel) and Syzygium aromaticum (clove buds) were purchased from local market of Lahore, during January 2012. Seeds of fennel and clove buds were packed in polythene bags and placed in a cooled and dried place for essential oil extraction. Leaves of Eucalytpus citriodora were collected from the University of the Punjab Quid-e-Azam Campus Lahore in the month of January, 2012. Fresh leaves were kept in refrigerator to be used for essential oil extraction.

Latex of Aloe vera barbedensis, Calotropis procera, Ficus elastic were collected from the nursery of University of the Punjab Quid-e-Azam Campus Lahore in the month of January, 2012.The plant species were identified by The Flora of Pakistan (Nasir \& Ali, 1978). The voucher specimen PU.IAGS.HHC.701 to Syzygium aromaticum (clove buds) PU.IAGS.HHC.702 to Eucalytpus citriodora and PU.IAGS.HHC.703 to Foeniculum vulgare were given and deposited in the Herbarium of Institute IAGS, (PU) Lahore. These plants are known to possess antiviral activity as reported previously.

\subsection{Extraction of Essential Oil}

$50 \mathrm{~g}$ seeds were powdered using domestic model grinder and were submitted to hydro distillation for 5 hours in a dean and stark assembly. The fresh leaves of Eucalytpus citriodora were washed to remove the dust particles and submitted to hydro-distillation for 5 hours in a Clevenger type stainless steel assembly. The extracted essential oil thus attained were dehydrated over anhydrous sodium sulphate and left overnight to remove traces of moisture. Then filtered and kept in black vials at $4^{\circ} \mathrm{C}$ until ready for use. Weight of essential oil was measured and yield was obtained by using the given formula.

$$
\text { Yield }(\%)=\frac{\text { Weight of extract recovered }}{\text { Weight of fresh leaves }} \times 100
$$

\subsection{Latex Collection and Fractionation}

Latex of Ficus elastic and Calotropis procera was obtained at morning from cultivated plants in the nursery of University of the Punjab Quid-e-Azam Campus Lahore in the month of January, 2012. Superficial incisions on young stems of the trees provided milk like latex. The resulting latex drops were collected in ice-chilled plastic recipient into sterilized distilled water. Natural coagulation of the latex was partially inhibited by gentle agitation while collecting. When a volume of latex equal to the starting volume of water was collected, the mixture was centrifuged for $20 \mathrm{~min}$ at $17,000 \mathrm{rpm}\left(4^{\circ} \mathrm{C}\right)$ on the same day as collected. The latex alienated into three layers; the white colored upper region comprising natural rubber; a central yellow clear aqueous layer called serum and the lowest layer having a small quantity of lipids particles. The serum fraction was separated. Aloe vera latex tapping from leaves on cutting was collected as such. The latex were preserved at $4^{\circ} \mathrm{C}$, and then tested for its antiviral activity.

\subsection{Extract Dissolution}

Sterilized glass vials were used for extract dissolution. Solutions of $10 \%$ and $5 \%$ latices and essential oils were made in distilled water adjusted with $0.1 \%$ Tween-20. These solutions were kept in the refrigerator at $4^{\circ} \mathrm{C}$ for antiviral activities. Once the solutions were prepared, these were sterilized using a $0.45 \mu \mathrm{m}$ membrane filter.

\subsection{Potential PLRV Positive Potato Plants}

Potato leaf roll virus infected plants were obtained from Centre of Excellence in Molecular Biology, University of the Punjab, Lahore. The virus infected plants were maintained on MS media at $25^{\circ} \mathrm{C}$ until use. The pathogenicity test of infected plants was done by RT-PCR and ELISA.

\subsection{Antiviral Activity}

\subsubsection{In-Vitro Culturing}

Murashige \& Skoog (1962) basal media supplemented with growth regulators was used during the studies pertaining to formation of virus infected plants. The $\mathrm{pH}$ of the medium was attuned to 5.7. The media was solidified by $3 \mathrm{~g} \mathrm{~m} / \mathrm{L}$ phytagel (Sigma). Sucrose was used as carbon source at a concentration of $3 \%$ in all media. All tissue culturing was carried out in sterilized environment under a laminar airflow cabinet. 


\subsubsection{Explant Preparation}

Apical portions consisting of 6-month-old potato plants were collected from the field and washed in a detergent-water mixture for 20 minutes. The water was poured off and the washing process was repeated 3 times and rinsed with distilled water finally. The plant nodes were cut into smaller pieces about 1 to $2 \mathrm{~cm}$ across each section containing a node with sterilized blades. The isolated plant sections were surface-sterilized with $0.1 \%$ $(\mathrm{w} / \mathrm{v})$ mercuric chloride $\left(\mathrm{HgCl}_{2}\right)$ for $10 \mathrm{~min}$, and washed in sterile distilled water three times. The sterilized plant nodes were retained on the filter paper to dry and placed onto the culturing media. The tubes were plugged with cotton plug and placed in a well-lit area to provide 16 hours of light per day.

\subsubsection{Acclimatization}

In-vitro cultured potato plants having sufficiently developed root system were transferred into soil. Each plant was carefully removed from its tube with a forceps avoiding any damage to the roots and planted into a small pot. The entire medium was washed off gently prior to planting. A hole was made in soil with thumb and roots were placed in it. Soil was pressed gently and carefully around the roots. Plants were watered 3 or 4 times a week on alternative days depending on the weather and green-house conditions.

\subsection{Evaluation of Extracts Efficiency against PLRV}

Essential oil and latex spray solutions were prepared at 5 and $10 \%$ concentration in distilled water adjusted with $0.1 \%$ Tween-20. Three the sprayings were done at 7 days interval for three PLRV infected plants per treatment at 5-7 leaf stage. PLRV infected plants after $3^{\text {rd }}$ spray of clove essential oil and Aloe vera latex are shown in Figure 1.

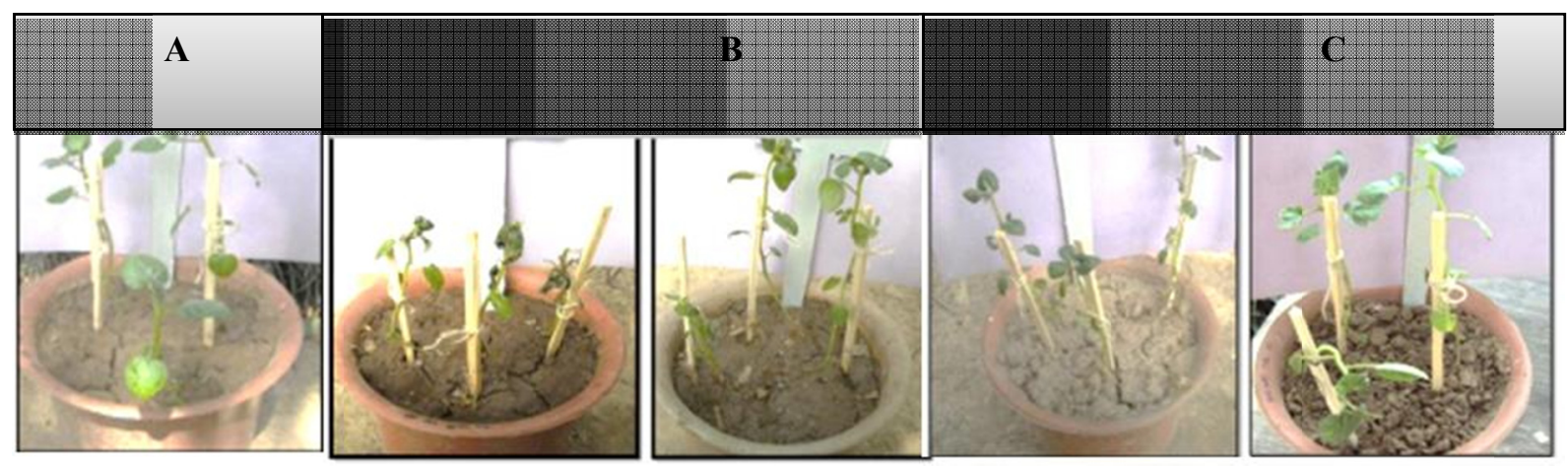

Figure 1. A: Control, B: PLRV infected plants after $3^{\text {rd }}$ spray of clove essential oil, C: PLRV infected plants after $3^{\text {rd }}$ spray of Aloe vera latex

\subsubsection{RNA Extraction}

The potato plants were ground in liquid nitrogen to form fine powder and poured into eppendorfs. $500 \mu \mathrm{L}$ of Trizol (Invitrogen) was added and placed at room temperature for $5 \mathrm{~min} .0 .2 \mathrm{~mL}$ of chloroform per $1 \mu \mathrm{L}$ of Trizol reagent was added and shaked vigorously for 10 seconds. The samples were incubated at room temperature for 3 minutes and centrifuged at $13,000 \mathrm{rpm}$ for $15 \mathrm{~min}$ at $4^{\circ} \mathrm{C}$. After centrifugation, the mixture was separated into lower red, phenol-chloroform phase, an interphase, and upper aqueous colorless phase. Upper aqueous phase was collected carefully without disturbing the interphase into separate eppendorf and $0.5 \mathrm{~mL}$ of isopropanol per $1 \mathrm{~mL}$ of Trizol was added for the precipitation of the RNA from the aqueous phase. Samples were incubated at room temperature for 5-10 min and centrifuged at $12,000 \mathrm{rpm}$ for 15 minutes at $4^{\circ} \mathrm{C}$. The supernatant was removed completely. The RNA pellet was washed once with $150 \mu \mathrm{L}$ of $70 \%$ ethanol. The samples were mixed by vortexing and centrifuged at 7,200 rpm for 5 minutes at $4^{\circ} \mathrm{C}$. All left over ethanol was removed. RNA pellet was air dried for 5-10 minutes and RNA was resuspended in $20 \mu \mathrm{L}$ of DEPC-treated water.

\subsubsection{RNA Quantification}

$1 \mu \mathrm{L}$ of undiluted RNA was quantified by NanoDrop 1000. The readings were taken against 260/280 nm wavelength. 


\subsection{3 cDNA}

$1 \mu \mathrm{g}$ of total RNA was used for cDNA synthesis. For this $1 \mu \mathrm{g}$ of template RNA, $1 \mu \mathrm{L}$ oligo (dT) $)_{18}$ primer and nuclease free water was added to the sterile, nuclease free vials on ice to make the volume up to $12 \mu \mathrm{L}$. These ingredients were mixed gently, centrifuged and incubated at $65^{\circ} \mathrm{C}$ for $5 \mathrm{~min}$. Then quick chilled on ice and spined. The vials were placed back on the ice and added $4 \mu \mathrm{L} 5 \mathrm{X}$ reaction buffer, $1 \mu \mathrm{L}$ RiboLock RNase Inhibitor $(20 \mathrm{u} / \mu \mathrm{L})$, $2 \mu \mathrm{L} 10 \mathrm{mM}$ dNTP and $1 \mu \mathrm{L}$ of RevertAid M-MuLV Reverse Transcriptase $(200 \mathrm{u} / \mu \mathrm{L})$. The reagenst were spun down and incubated at $42^{\circ} \mathrm{C}$ for $60 \mathrm{~min}$ followed by $5 \mathrm{~min}$ at $70^{\circ} \mathrm{C}$. The cDNA was stored at $-20^{\circ} \mathrm{C}$.

\subsubsection{Polymerase Chain Reaction}

cDNA was amplified for capsid protein gene of PLRV in treated and control plants. Each PCR reaction mixture was prepared in a sterile $0.2 \mathrm{ml}$ PCR tube having $2 \mu \mathrm{L}$ of $1 \mathrm{mM}$ dNTPs, $2 \mu \mathrm{L}$ of $10 \mathrm{X}$ PCR buffer, $2.5 \mathrm{mM} \mathrm{MgCl}_{2}$, $2 \mu \mathrm{L}$ of forward primer, $2 \mu \mathrm{L}$ of reverse primer, $2.5 \mu \mathrm{L}$ of Taq polymerase, $4 \mu 1$ of cDNA and $5 \mu \mathrm{L}$ of PCR water making final volume up to $20 \mu \mathrm{L}$. The reactions were subjected to 35 cycles, after an initial denaturation at $95^{\circ} \mathrm{C}$ for 5 minutes followed by 35 cycles of 1 minute at $94^{\circ} \mathrm{C}, 1$ minute at $55^{\circ} \mathrm{C}$ and 1 minute at $72^{\circ} \mathrm{C}$ with a final 10 minutes extension at $72^{\circ} \mathrm{C}$. PCR reactions were analyzed by $1 \%$ Agarose gel electrophoresis in $1 \mathrm{X}$ TAE buffer. A DNA ladder (1 kb, Fermantas) was used as molecular weight marker. The gels were photographed under UV light, using a Gel-documentation system.

\subsection{Physical Characterization of Essential Oil}

Physical characteristics of essential oil of Eucalytpus citriodora, Foeniculum vulgare and Eugenia caryophyllata were noted.

\subsubsection{Solubility of Oil}

Solubility of essential oil was examined in different solvents showed that the oil was insoluble in water while soluble in alcohol and ether.

\subsubsection{Specific Gravity}

The specific gravity of an essential oil at $20^{\circ} \mathrm{C}$ may be defined as the ratio of the weight of given volume of oil at $20^{\circ} \mathrm{C}$ to the weight of an equal volume of water at $20^{\circ} \mathrm{C}$. For determining the specific gravity, a specific gravity bottle having a volume capacity of $10 \mathrm{cc}$ was taken. The bottle was cleaned with acetone, removed the fumes with the aid of air blast and permitted the specific gravity bottle to dry thoroughly. The specific gravity bottle was filled with the reference liquid (water), and its weight was recoded on electric balance. Then emptied the same bottle, dried it and filled with the oil and weighted it accurately. The weight of oil contained in the specific gravity bottle was divided by the weight of equal volume of water in specific gravity.

$$
\text { Specific gravity }=\frac{\text { Density of the liquid at } 20^{\circ} \mathrm{C}}{\text { Density of } \mathrm{H}_{2} \mathrm{O} \text { at the same temperature }}
$$

\subsubsection{Refractive Index}

The refractive index of the oil was measured on the Abbe's Refractometer Atago 3T. The refractometer was standardized using distilled water at room temperature. A drop of oil placed between two prisms of refractometer and reading of refractive index was measured.

\subsection{Phytochemical Analysis}

Qualitative phytochemical analysis of the essential oils and latex were determined .These tests were done to find the occurrence of the active chemical components i.e., alkaloids, cardiac glycosides, saponins, sterols, tannins etc.

\subsubsection{Alkaloids (Mayer's Test)}

$10 \mathrm{ml}$ methanol was added to $200 \mathrm{mg}$ of sample and filtered. $2 \mathrm{~mL}$ filtrate was mixed with $1 \% \mathrm{HCl}$ and mixture was heated. Then $1 \mathrm{~mL}$ was taken and 6 drops of Mayer's reagent was added. Formation of white yellow precipitate on addition of Mayer's reagent shows the presence of alkaloids (Evans, 1997).

\subsubsection{Cardiac Glycosides}

$0.5 \mathrm{~g}$ m of sample was mixed with $2 \mathrm{~mL}$ of chloroform. Then concentrated sulphuric acid was added carefully. A lower transparent layer was formed which shows the presence of cardiac glycosides (Salkowski test). 


\subsubsection{Flavonoids}

$5 \mathrm{~mL}$ of sample solution was mixed with $1.5 \mathrm{~mL}$ of $50 \%$ methanol solution. This solution was heated and magnesium metal was added. 5-6 drops of concentrated hydrochloric acid was added to it and appearance of red color depicts the presence of flavonoids (Siddiqui \& Ali, 1997).

\subsubsection{Tannins}

1-2 drops of ferric chloride solution and $1 \mathrm{~mL}$ of water was added to $0.5 \mathrm{~mL}$ of sample. Greenish brown color appeared which depicts the presence of tannins (Iyengar, 1995; Trease \& Evans, 1989).

\subsubsection{Saponins (Foam Test)}

$30 \mathrm{~mL}$ of water was added to $1 \mathrm{gm}$ of sample and boiled for 10 minutes. Persistent formation indicated the presence of saponins (Wall, Eddy, McClennan, \& Klump, 1952; Wall et al., 1954).

\subsubsection{Phylobatannins}

Sample was boiled with $1 \%$ aqueous $\mathrm{HCl}$. Deposition of red precipitates indicated the presence of pylobatannins (Evans, 2002).

\subsubsection{Sterols (Acidic Reagent Test)}

$2 \mathrm{~mL}$ of concentrated sulphuric acid was added to the sample and the appearance of brownish color at interface was indicating the presence of Sterols (Salkowski's Test).

\subsubsection{Terpenes}

$3 \mathrm{~mL}$ of chloroform was added to $0.5 \mathrm{gm}$ of sample, shaken together and filtered. Then 10 drops of acetic anhydride and 2 drops of concentrated sulphuric acid were added reddish brown precipitate depicted the presence of terpenes (Sofowora, 2008).

\subsection{GC-MS Analysis}

GC-MS analysis of three essential oils namely Clove oil, Eucalyptus oil and Fennel oil was carried out from Department of Chemistry Government College University, Lahore, Pakistan. GC-MS analysis were done using a Perkin-Elmer GC clauses 500 system and Gas Chromatograph interfaced to a mass spectrometer (GC-MS) equipped with Elite-1, fused silica capillary column. The relative percentage amount of each component was calculated by comparing its average peak area to the total areas, software adopted to handle mass spectra and chromatograms was a Turbo mass. Interpretation of mass spectrum of GC-MS was conducted using the database of National Institute Standard and Technology (NIST) having more than 62,000 patterns. The spectrum of the known constituent was compared with the spectrum of the known constituents stored in the NIST library. The name, molecular weight and structure of the components of the test materials were ascertained.

\section{Results}

\subsection{Antiviral Activity of Essential Oils and Latices against PLRV}

Inhibition of mRNA expression of PLRV capsid protein gene was detected by amplification of the viral capsid protein gene using RT-PCR technique. The test essential oils and plants latex were considered to be active when it has the ability of inhibiting the viral mRNA expression of target gene, as demonstrated by the disappearance or decrease in intensity of strands RNA amplified products noticed by the RT-PCR when compared to positive control. Out of the tested essential oils and latex, A. vera latex (10\%) proved to inhibit PLRV mRNA expression of CP gene almost completely at $10 \%$ concentration as shown in Figure $2(*$ shows decrease in intensity of band and ** increase in intensity of band). Clove essential oil also showed strong viricidal activity as band intensity was lowest next to A.vera latex as shown in Figure 3. Overall all the selected essential oils and latexes showed pronounced antiviral effect and the effect was found concentration dependent increasing as the concentration of applied essential oil and latices increases from 5-10\% as shown in Figures 2 and 3. 


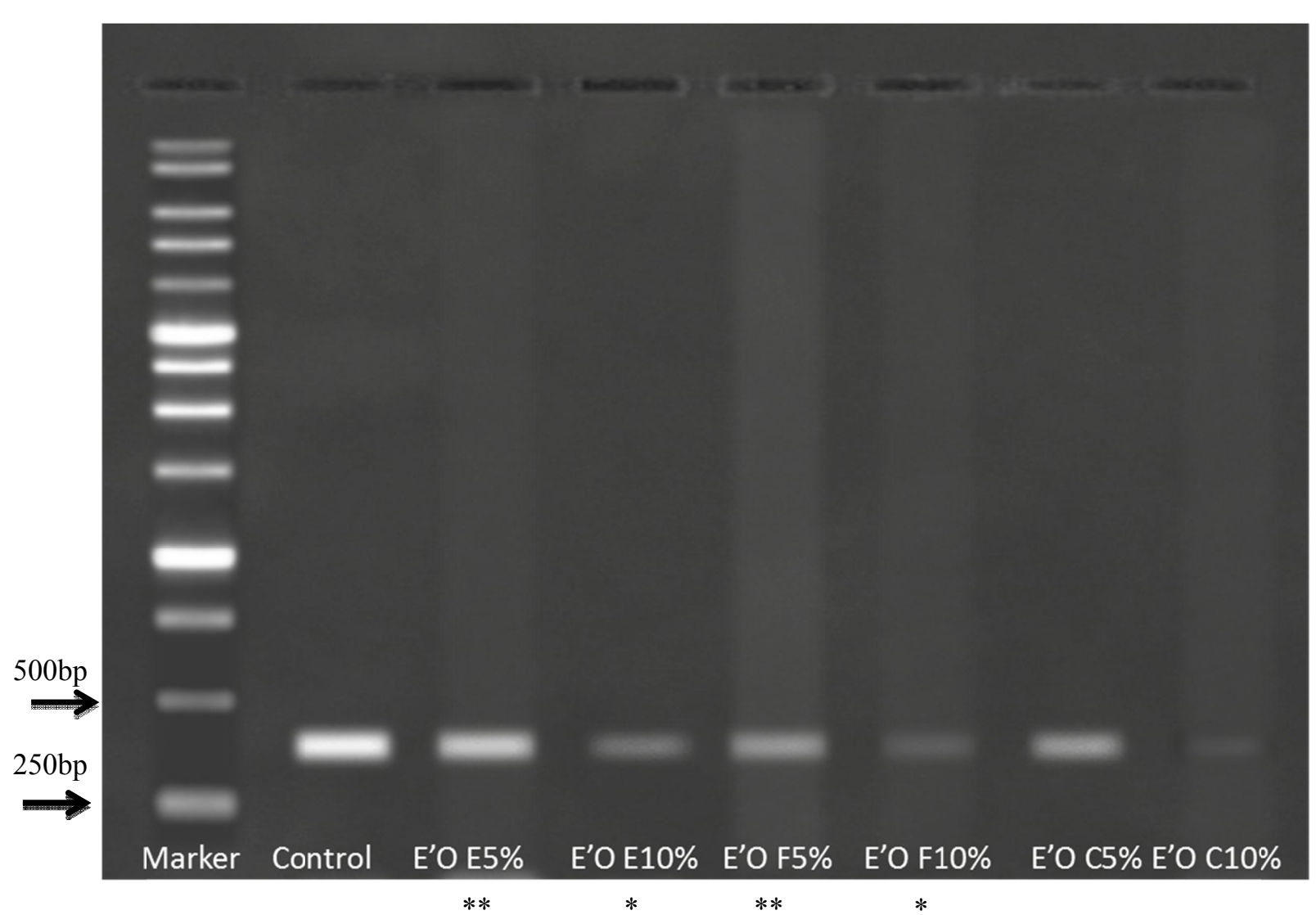

Figure 2. Amplification of the PLRV capsid protein gene extracted from E'O treated plants using RT-PCR technique

(* shows decrease in intensity of band and $* *$ increase in intensity of band).

(E'OC: Essential oil of clove, E'OE: Essential oil of Eucalyptus, E'OF: essential oil of Fennel). 


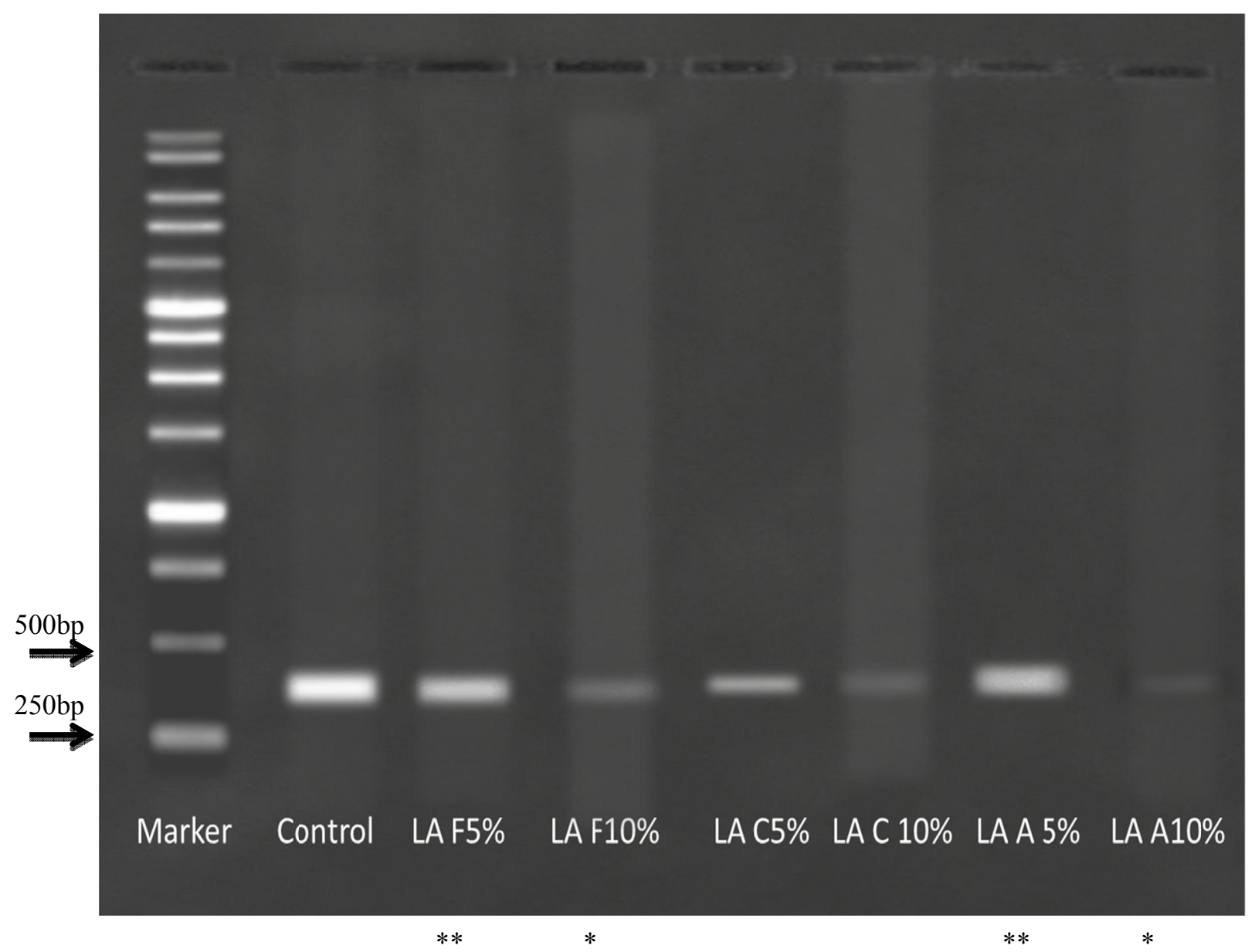

Figure 3. Amplification of the PLRV capsid protein gene extracted from latex treated plants using PCR technique (* shows decrease in intensity of band and ** increase in intensity of band).

(LA A: Latex of Aloe vera, LA C: Latex of Calotropis procera, LA F: Latex of Ficus elastica).

\subsection{Percentage yield of essential oils}

Percentage yield of essential oils from leaves of Eucalytpus citriodora, Foeniculum vulgare and Syzygium aromaticum was calculated. Maximum percentage yield of $5.1 \%$ was obtained in case of Clove essential oil followed by $3.2 \%$ in Eucalytpus citriodora and 2.3\% in Foeniculum vulgare (Table 3.1).

Table 1. Percentage Yield of essential oils from leaves of Eucalytpus citriodora, Foeniculum vulgare and Syzygium aromaticum

\begin{tabular}{ll}
\hline Essential oil & $\%$ Yield \\
\hline Eucalytpus citriodora & $3.2 \%$ \\
Syzygium aromaticum (Clove) & $5.1 \%$ \\
Foeniculum vulgare (Fennel) & $2.3 \%$ \\
\hline
\end{tabular}

\subsection{Physical Characterization of Essential Oil}

Physical characteristics including color, odor, specific gravity, refractive index, optical density and solubility of essential oils of Eucalytpus citriodora, Eugenia caryophyllata and Foeniculum vulgare was calculated. Clove 
essential oil has maximum specific gravity of 1.036 whereas fennel essential oil has maximum refractive index of 1.534 at $72^{\circ} \mathrm{F}$. All the essentials oils were soluble in ether and alcohol while insoluble in water (Table 2).

Table 2. Physical characterization of Essential Oil

\begin{tabular}{llll}
\hline \multirow{2}{*}{ Physical characteristics } & \multicolumn{3}{c}{ Essential Oil } \\
\cline { 2 - 4 } & Eucalytpus citriodora & Syzygium aromaticum (Clove) & Foeniculum vulgare (Fennel) \\
\hline Color & Brownish yellow & Pale yellow & Clear with a Faint Yellow Tinge \\
Odor & Woody earthy fresh & Warm, strong, spicy & Herby, slightly spicy \\
Specific gravity at $72^{\circ} \mathrm{F}$ & 0.9207 & 1.036 & 0.963 \\
Refractive index at $72^{\circ} \mathrm{F}$ & 1.4652 & 1.531 & 1.534 \\
Optical Rotation & -1.73 & -1.43 & +22.4 \\
Solubility in Alcohol and Ether & Fairly soluble & Fairly soluble & Fairly soluble \\
\hline
\end{tabular}

\subsection{Phytochemical Screening of Essential Oils and Latex}

The screening of the chemical components was carried out for essential oils and latex. Maximum amount of alkaloids was present in Eucalytpus oil. Cardiac glycosides were present in all the essential oils while absent in all latices. More flavonoids were present in fennel oil as compared to other oils and present only in Aloe vera latex. Phenols were present in all essential oils and latices except Ficus elastica latex. Phlobatanins were present only in clove and Eucalyptus oil. More saponins were present latices in comparison with essential oils. Sterols were present only in essential oils. Tanins were abundant in clove oil and Aloe vera latex. Terpenes were present in all oils and only in Aloe vera latex. Essential oils were found greater in capacity of all the active phytochemicals as compared to plants latex, except phlobatannins in fennel oil and saponins in clove oil which were absent. Among all the test plants latex, A.vera latex was enriched in bioactive compounds as compared to other two latex. (Table 3).

Table 3. Screening of essential oils and latex for phytochemical properties

\begin{tabular}{|c|c|c|c|c|c|c|}
\hline \multirow{2}{*}{ PHYTOCHEMICALS } & \multicolumn{3}{|c|}{ Essential Oils } & \multicolumn{3}{|c|}{ Latex } \\
\hline & Clove & E. citriodora & Fennel & Aloe vera & C. procera & F. elastica \\
\hline Alkaloids & ++ & +++ & + & ++ & + & + \\
\hline Cardiac glycosides & + & + & + & - & - & - \\
\hline Flavonoids & + & + & ++ & + & - & - \\
\hline Phenols & + & + & ++ & + & + & - \\
\hline Phlobatannins & + & + & - & - & - & \\
\hline Saponins & - & + & + & ++ & ++ & +++ \\
\hline Sterols & +++ & +++ & ++ & - & - & - \\
\hline Tannins & ++ & + & + & ++ & + & + \\
\hline Terpenes & ++ & + & + & + & - & - \\
\hline
\end{tabular}

As shown in Table 3, - absent, $+:>50 \%$, compared with control, $++: 50 \%<80 \%,+++:>80 \%$.

\subsection{GC-MS Spectra of Essential Oils}

The essential oil extracted from cloves comprises $68.65 \%$ of Eugenol, and is the compound most accountable for the aroma of cloves. Other significant essential oil constituents of clove oil comprise acetyleugenol $27.97 \%$ and caryophyllene 3.39\% (Table 4, Figures 4 and 5). 
Table 4. Phytocomponents Identified in (Syzygium aromaticum) clove buds

\begin{tabular}{llllll}
\hline No & RT & Name of the compound & Molecular Formula & MW & Peak Area \% \\
\hline 1. & 7.476 & Eugenol & $\mathrm{C}_{10} \mathrm{H}_{10} \mathrm{O}_{2}$ & 164 & 68.65 \\
2. & 8.150 & Caryophyllene & $\mathrm{C}_{15} \mathrm{H}_{24}$ & 204 & 3.39 \\
3. & 8.751 & Acetyleugenol & $\mathrm{C}_{12} \mathrm{H}_{14} \mathrm{O}_{3}$ & 206 & 27.97 \\
\hline
\end{tabular}

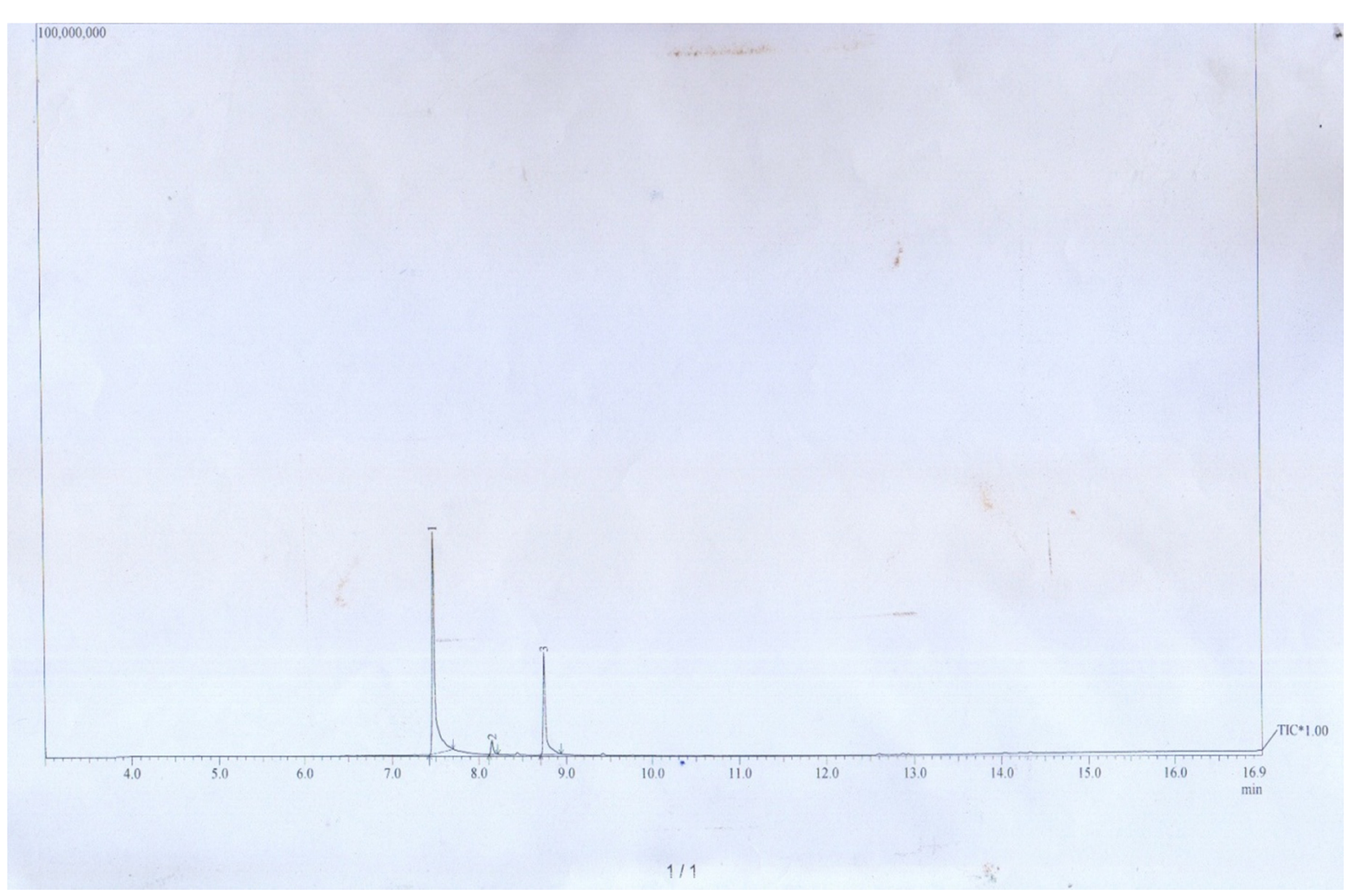

Figure 4. GC-MS spectra of clove essential oil 
<smiles>C=CCc1ccc(O)c(OC)c1</smiles>

Eugenol<smiles>CCCc1ccc(O)c(OC)c1</smiles>

Cis-isoeugenol<smiles>C=CCc1ccc(OC(C)=O)c(OC)c1</smiles>

Acetyleugenol<smiles>C=CCc1cccc(OC)c1O</smiles>

o-Eugenol

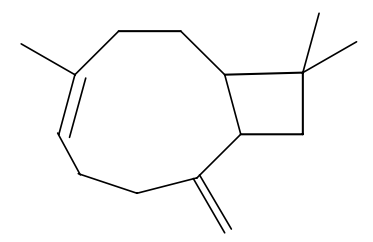

Bicyclo[7.2.0]undec-4-ene

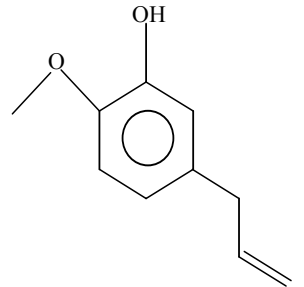

3-Allyl-6-methopxyphenol

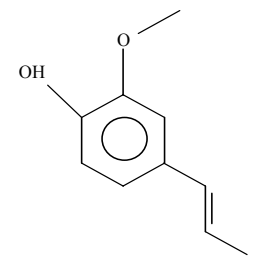

$\mathrm{OH}$

2-methoxy-4-(1-propenyl)-, [Eugenol]<smiles>C/C=C/c1ccc(OC(C)=O)c(OC)c1</smiles>

Acetisoeugenol

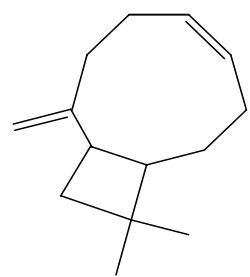

Caryophyllene

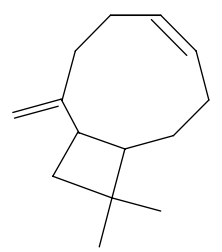

Bicyclo[7.2.0] undec-4-ene

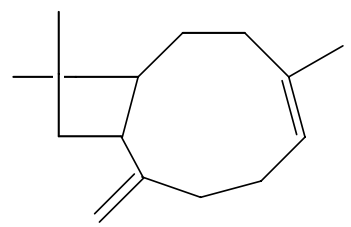

\section{Isocaryophillene}

Figure 5. Phytocomponents identified in (Syzygium aromaticum) clove buds 
The essential oil extracted from eucalyptus leaves comprises $83.19 \%$ of Eucalyptol. This compound is considered as most responsible for the eucalyptus aroma. Other imperative essential oil components of eucalyptus oil include 6.87\% alpha-pinene, $6.87 \%$ D-Limonene, 1.60\%, alpha-terpineol and 1.47\% glubulol (Table 5, Figures 6 and 7 ).

Table 5. Phytocomponents identified in Eucalyptus citriodora

\begin{tabular}{llllll}
\hline No & RT & Name of the compound & Molecular Formula & MW & Peak Area $\%$ \\
\hline 1. & 3.045 & alpha-pinene & $\mathrm{C}_{10} \mathrm{H}_{16}$ & 136 & 6.87 \\
2. & 4.03 & D-Limonene & $\mathrm{C}_{10} \mathrm{H}_{16}$ & 136 & 6.87 \\
3. & 4.100 & Eucalyptol & $\mathrm{C}_{10} \mathrm{H}_{18} \mathrm{O}$ & 154 & 83.19 \\
4. & 5.950 & Alpha-terpineol & $\mathrm{C}_{10} \mathrm{H}_{18} \mathrm{O}$ & 154 & 1.60 \\
5. & 9.430 & Glubulol & $\mathrm{C}_{15} \mathrm{H}_{26} \mathrm{O}$ & 222 & 1.47 \\
\hline
\end{tabular}

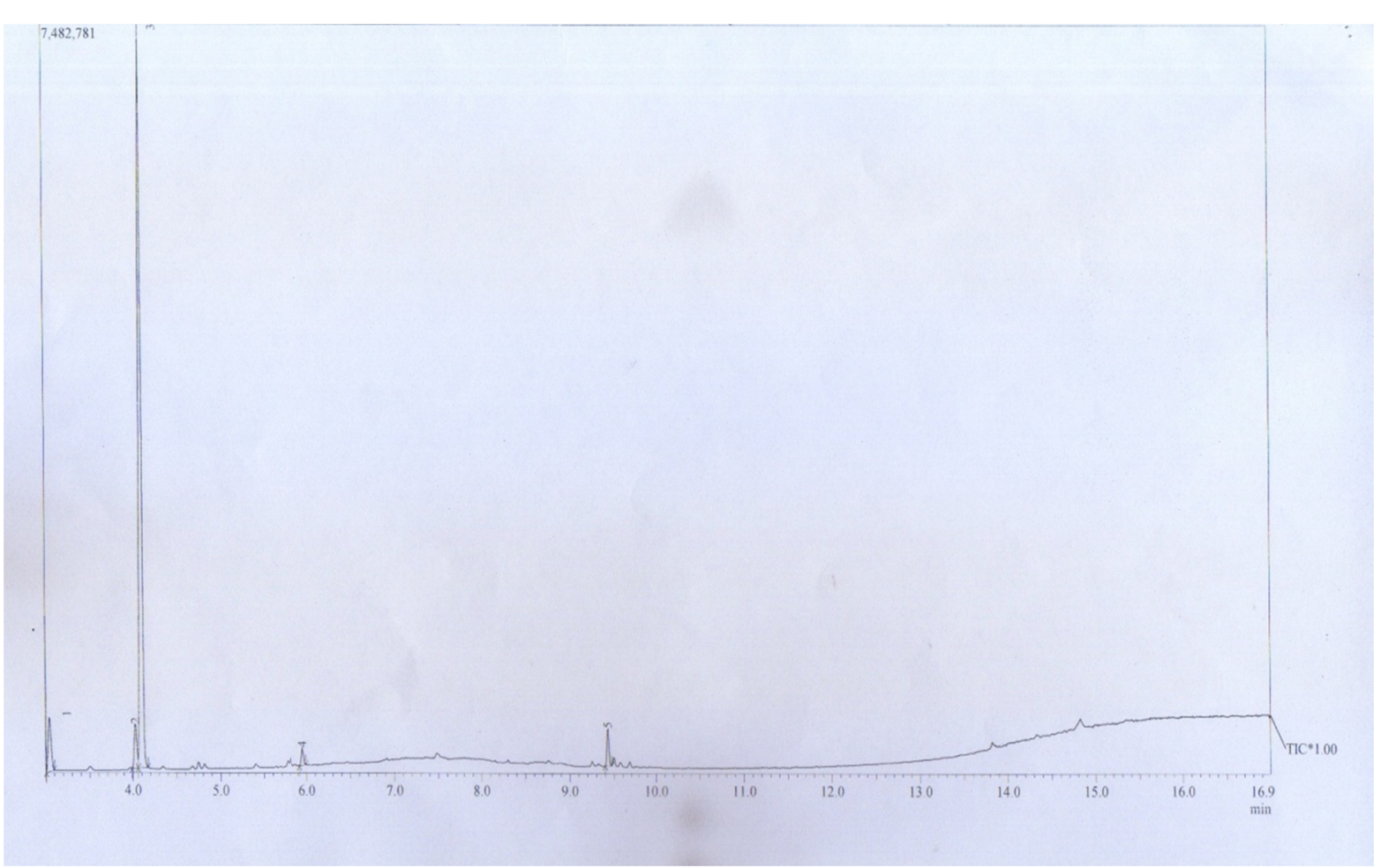

Figure 6. GC-MS spectra of ecalytpus essential oil 


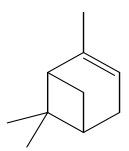

Alpha.-Pinene<smiles>C=C1CCC2CC1C2(C)C</smiles>

Bicyclo[3.1.1]hept-2-ene<smiles>C=C(C)C1CC=C(C)CC1</smiles>

D-Limonene<smiles>C=C(C)C1CCC=C(C)C1</smiles>

m-Mentha-6,8-diene<smiles>CC1=CCC(COC(=O)C(F)(F)I)CC1</smiles>

alpha-terpineol<smiles>CC1CCC(C)CC1</smiles>

alpha-Terpineol<smiles>C=CC(C)=CCCC(C)(C)O</smiles>

Ocimenol

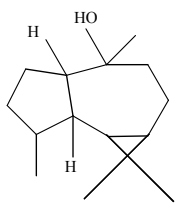

Epiglobulol<smiles>CC1=CCC2CC1C2(C)C</smiles>

2,6,6-Trimethylbicyclo[3.1.1]hept-2-ene<smiles>CC1CCC2CC1C2(C)C</smiles>

L-alpha-Pinene<smiles>CC(C)C1CCC2CC3CC(C2)C1C3</smiles>

L-Limonene<smiles>CC(C)C12CCC(C)(CC1)CC2</smiles>

Eucalyptol<smiles>C=C(C)C1CCC(C)(O)CC1</smiles>

Terpineol<smiles>CC1=CCC(C(C)(C)C)CC1</smiles>

p-mentha-1-ene-8-ol

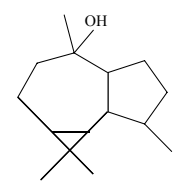

Globulol

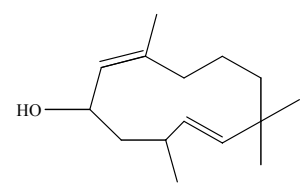

Humulane-1,6-dien-3ol

Figure 7. Phytocomponents identified in Eucalyptus citriodora 
The essential oil extracted from fennel seeds comprises $61.97 \%$ of p-Allylanisole, $21.94 \%$ Anisole, $6.60 \%$ L-Fenchone, 5.04\% Eucalyptol and 4.45\% Limonene (Table 6, Figures 8 and 9).

Table 6 Phytocomponents Identified in (Foeniculum vulgare) Fenel seeds

\begin{tabular}{llllll}
\hline No & RT & Name of the compound & Molecular Formula & MW & Peak Area \% \\
\hline 1. & 7.234 & D-Limonene & $\mathrm{C}_{10} \mathrm{H}_{16}$ & 136 & 4.45 \\
2, & 7.288 & Eucalyptol & $\mathrm{C}_{10} \mathrm{H}_{18} \mathrm{O}$ & 154 & 5.04 \\
3. & 7.910 & L-Fenchone & $\mathrm{C}_{10} \mathrm{H}_{16} \mathrm{O}$ & 152 & 6.60 \\
4. & 8.919 & Anisole & $\mathrm{C}_{10} \mathrm{H}_{12} \mathrm{O}$ & 148 & 21.94 \\
5. & 9.685 & p-Allylanisole & $\mathrm{C}_{10} \mathrm{H}_{12} \mathrm{O}$ & 148 & 61.97 \\
\hline
\end{tabular}

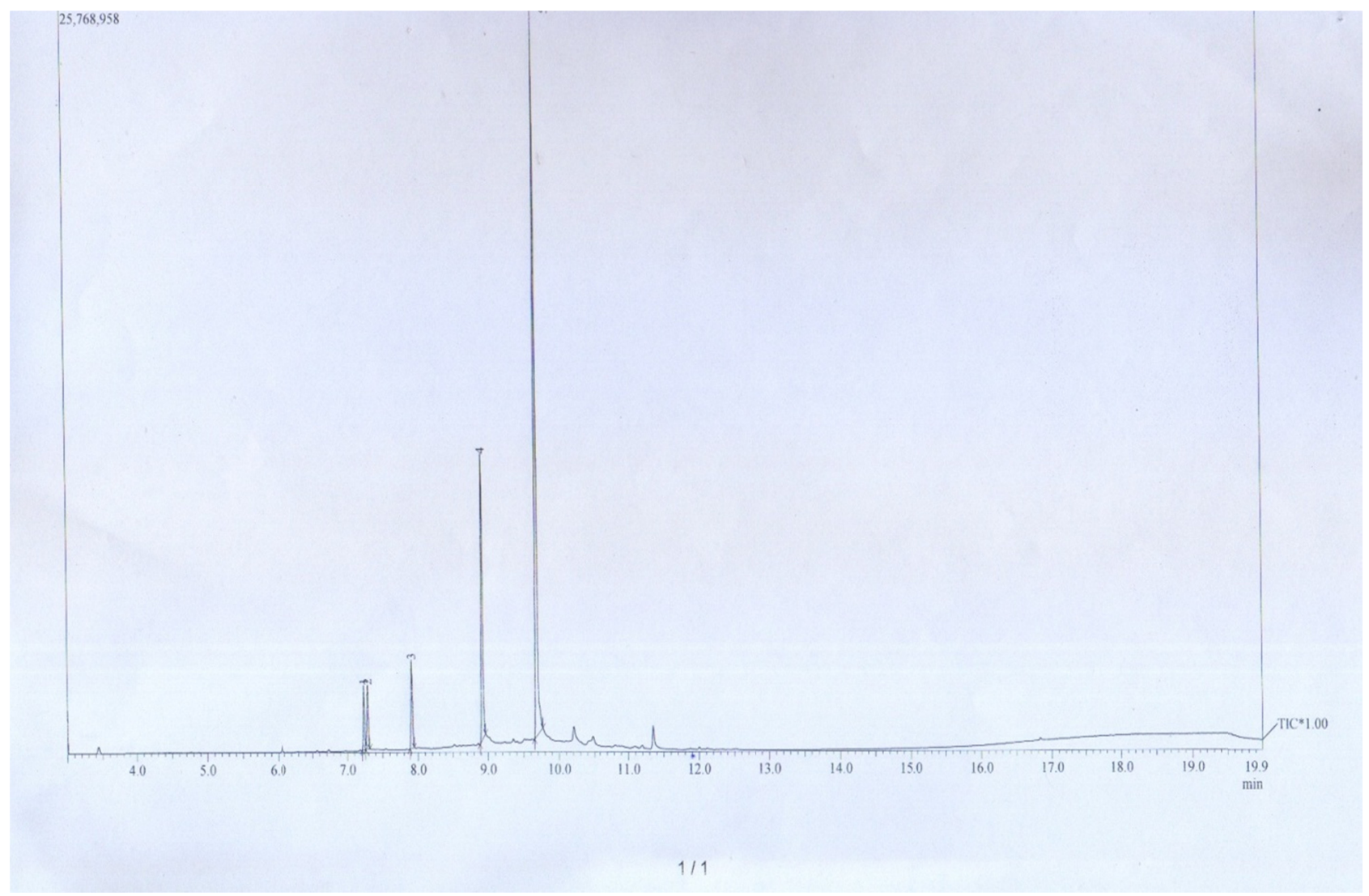

Figure 8. GC-MS Spectra of Fennel Essential oil 
<smiles>C=C(C)C1CC=C(C)CC1</smiles>

D-Limonene

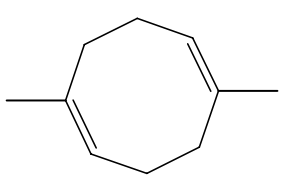

1,5-Dimethyl-1,5-cyclooctadiene<smiles>C=C(C)C1CCC(C)(O)CC1</smiles>

\section{Cis-beta-Terpineol}<smiles>C/C=C/c1ccc(OC)cc1</smiles>

Anisole<smiles>C=CCc1cc(C)ccc1O</smiles>

2-Allyl-4-methylphenol<smiles>C=C(C)C1CC=C(C)CC1</smiles>

L-Limonene<smiles>CC(C)C1CCC2(C)CCC1C2</smiles>

Eucalyptol

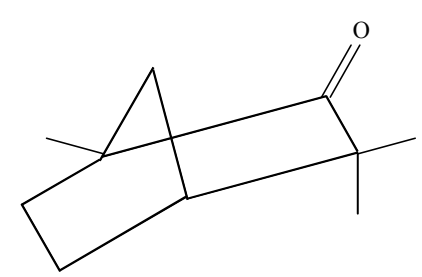

L-Fenchone<smiles>C=CCc1ccc(OC)cc1</smiles>

p-Allylanisole<smiles>C/C=C/c1ccc(OC)cc1</smiles>

p-(1-Propenyl)anisole<smiles>C=CCc1ccc(OC)cc1</smiles>

p-Allylanisole

Figure 9. Phytocomponents identified in Foeniculum vulgare seeds 


\section{Discussion}

Potato leaf roll virus (PLRV, genus Polerovirus, group Luteovirus, family Luteoviridae) is one of the most damaging viruses on potato. It infects the potato wherever they are grown and results in considerable loss in yield, which may reach up to $50 \%$ (Hamm \& Hane, 1999). Several efforts have been made to control the disease caused by PLRV and to improve the growth of plants by using some chemicals. Some essential oils from herbal teas, kitchen spices and culinary herbs have also exhibited marked antiviral potential. Apart from the importance of plants as source of food placed by man, their other great use has been in the area of medicine and phytomedicine. Numerous plants belonging to different families produce essential oils and latex, it is accumulated in over 2000 species of plants. It is well known that essential oils and latices contain several enzymatic and inhibitory potential against pathogens, viruses and insects (Sritanyarat et al., 2006). Plants and their essential oils have variable degree of antimicrobial potential (Juven, Kanner, Schved, \& Weisslowicz, 1994; Chang, 1995). Essential oils and their constituents have shown good potential to control drug resistant pathogens (Sonboli, Babakhani, \& Mehrabian, 2006; Chavan et al., 2006; Cowan, 1999; Ahmad et al., 2001). Sabry et al. (2010) screened latices tapped from Ficus elastica, F. nitida and Euphorbia pulcherrimia plants for antiviral activity against some plant viruses in different hosts. The greatest degree of antiviral activity observed when the latex of F. nitida was mixed with either BYMV or ZYMV for 15 min or pretreatment for $48 \mathrm{~h}$. Complete inhibition in local lesion numbers was achieved when serum latex of $F$. nitida was mixed with equal volume of purified TNV $-1(1 \mathrm{~g} \mathrm{ml}$ G) for $15 \mathrm{~min}$. A. vera possesses antifungal, antiviral, antibacterial and acaricidal activity (Mantle, Gok, \& Lennard, 2001). Studies have shown that Ficus latex possesses antimicrobial and a range of pharmacological activities (Augustus \& Seiler, 2011). Due to rapid spread of plant viruses, there was a need to explore novel antiviral agents against plant infection. In present investigation, the relative success achieved using medicinal plant essential oils and plant latices of various species. The antiviral activity of essential oils of Eucalytpus citriodora, Foeniculum vulgare and Syzygium aromaticum and latex tapped from Aloe vera, Calotropis procera and Ficus elastic was investigated against potato leaf roll virus (PLRV) using molecular marker. Our data showed that Aloe vera latex and clove essential oil caused maximum inhibition of intracellular viral replication at $10 \%$ concentration as shown in Figures 2 and 3. Our study proved that essential oils and latex of selected medicinal plants are proven to be potent antiviral agent against PLRV. Results depicted inhibitory potential of all the test essential oils and latex and the effect was found concentration dependent (Figures 2 and 3). These findings are in accordance with the previous work as done by Rakib et al. (2010) on Thuja orientalis and Artimisia campestris extracts which hinder multiplication of PLRV by 81.72 and $63.6 \%$ respectively.

Phytochemicals responsible for the activity are considered as saponins, flavonoids, alkaloids, terpenoids, furyl compounds, polyphenolics, sulphides, thiophenes, lignans, coumarins, peptides and proteins. Most of these phytochemicals have overlapping and complementary mode of action, involving antiviral activity either by preventing the viral DNA or RNA formation or inhibition of viral replication activity. Concerning chemical components, $A$. vera contains amino acids, lipids, sterols, tannins, enzymes chromones (flavonoids) and mannose -6-phosphate (Davis \& Robson, 1999). The results suggested that among plant latex, a component conjugates with protein virus and disintegrate it. Many antiviral proteins are reported to contain ribosome-inactivating proteins (RIPs). Kumon, Sasaki, Sejima, Takeuchi, \& Hagashi (1990) reported that antiviral proteins of pokeweed just $0.01 \mathrm{mg} / \mathrm{ml}$ is needed for inhibition of the TMV infection. Phenolic compounds like tannins and flavonoids are considered responsible for antioxidant properties of many plants (Larson, 1988). Structure and compositions of latices including defense-related proteins have been studied extensively (D. Wititsuwannakul, \& R. Wititsuwannakul, 2001). Phytochemical screening of $A$. vera plant showed the presence of alkaloids, carbohydrates, flavonoids, tannins, terpenoids, and absence of antiquinones, glycosides, saponins, steroids. phlobatannins, and carbohydrates (Raphael, 2012). Phytochemical analysis of the leaf and latex extracts of Calotropis procera showed the presence of flavonoids, tannins, steroids, saponins while alkaloids were absent in both extracts (Kawo et al., 2009). Phytochemical screening of water, methanol and ethanol extracts obtained from the fruit and bark of Calotropis procera were investigated and revealed the presence of alkaloids, cardiac glycosides, flavonoids, tannins, and saponins (Mainasara, Aliero, Aliero, \& Dahiru, 2011). The leaf and latex extract of Calotropis gigantea were analyzed for the presence of phytochemicals and it was found to contain aminoacids, anthraquinones, flavanoids, phenolic compound (Murugan, 2012). Phytochemical screening of the crude extract of Calotropis procera exhibited the presence of saponin, tannins, sequiterpene and alkaloids. Other phytoconstituents which were reported were cardiac glycosides, flavonoids, glycosides, steroid, terpens and tannins (Goyal \& Mathur, 2011). Phytochemical analysis on the genus Ficus displayed the presence of flavonoids (Mohammad, Sutradhar, Ahmad, \& Rnjit 1991), alkaloids (Ikhlas, Rali, \& Stigher, 1993), organic acids (Ilyas, 1990) and triterpenes (Beat, Clemens, Wright, Rali, \& Otto, 1990). Method was needed to link antiviral potency of essential oils/latex and plant virus PLRV. The selected essential oils of Eucalytpus 
citriodora, Foeniculum vulgare and Syzygium aromaticum and latices of Aloe vera, Calotropis procera and Ficus elastic were screened for phytochemicals responsible for antimicrobial action and showed considerable presence of phytochemicals especially in essential oils. Essential oil of Eucalytpus citriodora has maximum amount of alkaloids followed by Aloe vera latex. Cardiac glycosides were present in essential oils of Eucalytpus citriodora, Foeniculum vulgare and Syzygium aromaticum and absent in all latices. More flavonoids were present in fennel essential oils and Aloe vera latex only. These results are same as Arunkumar and Muthuselvam (2009) qualitatively analyzed the phytochemicals of Aloe vera. Tannin, saponin, flavonoids and terpenoids were present where as phlobactanins and steriods were absent. Phenols were present in all essential oils and latices except Ficus latex. Phlobatannins were present only in clove and Eucalyptus essential oils. Saponins were present in all oils and latices except clove oil. Maximum amount of sterols was present in clove and Eucalytpus essential oil. Tanins were present in all oils and latices while terpenes were absent in Calotropis and Ficus latex (Table 3). The phytochemical investigation of Calotropis procera indicated the presence of cardenolides, flavonoids, and saponins (Moustafa, Ahmed, Nabil, Hussein, \& Omran, 2010). Number of investigators has reported the efficacy of these phytochemicals having antiviral potential (Du, He, \& Jiang, 2003; Wei, C. Ma, \& Y. Ma, 2004).

The constituents in essential oils differ not only with plant species but also relative climate, soil conformation, plant part and age. GC and GC-MS analysis of the Eucalyptus oil (yield $0.6 \%$ ) depicted the monoterpenoid nature with citronellal (52.2\%), citronellol (12.3\%) and isoisopulegol (11.9\%) as the chief constituents and yield of the oil from the leaves varied between 1.0 to $2.1 \%$ in different months. Eucalyptus oil composition has been extensively investigated due to their numerous uses in the pharmaceutical and cosmetics industries (Ahmad, Hanit, \& Rashid, 2005). In present study yield of Eucalytpus essential oil was 3.2\% (Table 5). GC-MS analysis of Eucalyptus essential oils showed abundance of Eucalyptol (83.19\%). The other minor components were D-Limonene and alpha-pinene both 6.87\%, alpha-terpineol (1.60\%) and glubulol (1.47\%) (Table 5, Figures 6 and 7).

Eugenol encompasses $72-90 \%$ of the essential oil extracted from cloves, and is the compound most accountable for the cloves' aroma. Thirty one constituents were recognized in clove bud oil with the main components being eugenol (49.7\%), caryophyllene (18.9\%), benzene,1-ethyl-3-nitro (11.1\%) and benzoic acid,3-(1-methylethyl) (8.9\%) (Bhuiyan, Begum, Nandi, and Akter, 2010). Other vital essential oil components of clove oil comprise acetyl eugenol, beta-caryophyllene and vanillin; crategolic acid; tannins, gallotannic acid, methyl salicylate; the flavonoids eugenin, kaempferol, rhamnetin, and eugenitin; triterpenoids like oleanolic acid, stigmasterol and campesterol; and several sesquiterpenes (Bensky, Clavey, Stoger, \& Gamble, 2004). In present study, GC-MS analysis of essential oils showed abundance of Eugenol in clove buds (68.65\%). The other components includes caryophyllene (3.39) and acetyleugenol (27.97\%) (Table 4). These results are in accordance with the study done in 2005 by A. K. Srivastava \& S. K. Srivastava. They found the main components of Indian and Madagascan $S$. aromaticum bud oil were eugenol (70 and 82.6\%) and $\beta$-caryophyllene (19.5 and 7.2\%) (A. K. Srivastava \& S. K. Srivastava, 2005).

In current investigation, GC-MS analysis of fennel seed essential oil showed plenty of p-Allylanisole $61.97 \%$. The minor components were anisole (21.94), Eucalyptol (5.04), D-Limonene (4.45) and L-fenchone (6.60) (Table 6). The results are similar to the study in which oil obtained from $F$. vulgare was analyzed and a total of 33 compounds were found in essential oil of fennel by GC-MS equal to total $95.2 \%$. Whereas trans-anthole was major components of oil (70.1\%) followed by fenchone $(6.9 \%)$ and methyl chavicol $(4.8 \%)$ but the levels of other compounds were low (Gulfraz et al., 2008). Water-distilled essential oil from fennel was investigated by GC-MS and resulted in the identification of 50 compounds representing $96.03 \%$ of the oil. The main compounds of the essential oil were Benzene, 1-methoxy-4-(1-propenyl) - (82\%), D-Limonene (6.55\%), Estragole (3.53\%), 3-Carene (1.12\%) and 1, 6-Octadien-3-ol, 3,7-dimethyl- (1.12\%) (Renjie, Zhenhong, and Shidi, 2010).

Hudson (1990) reported that many components extracted from higher plants have antiviral activity. Examples included tannins, flavones, alkaloids, that displayed in vitro activity against numerous viruses. The antiviral activities depicted by essential oils in the present research was due to presence of active phytochemicals which were absent in plant latices. All the analyzed phytochemicals have phenolic functional group enhancing bioactivity. As this research work illustrates, there is innumerable potential of medicinal plants essential oils/latices waiting to be assessed and exploited against functionally and genetically diverse plant viruses.

\section{Conclusion}

The development of new medicinal plant products is vibrant in controlling the intimidations posed by some pathogenic viruses. It can be fairly concluded that essential oils of Clove, Fennel and Eucalyptus and latex of Aloe vera have a great potential as sources for novel lead compounds with specific antiviral properties. The 
observations indicate that essential oils and $A$. vera latex can induce wide range of adverse reactions in sensitive microbes. Among all the test plants latex, A. vera latex was enriched in bioactive compounds as compared to other two latex. Essential oils were found greater in capacity of all the active phytochemicals as compared to plants latex, except phlobatannins in fennel oil and saponins in clove oil. This study supports the concept that, plant latices and essential oils may be important as a prospective tool of natural antiviral product, which may be benefit in plant viral control. The essential oils/latices were found operative, but more work is needed to formulate these compounds to make them more easy to use. We think that more struggles are needed to assimilate the proficient compounds with each other to become more operational toward the microbes of plant. Our study proved that essential oils and latex of selected medicinal plants are proven to be potent antiviral agent against PLRV.

\section{References}

Ahmad, A., \& Beg, A. Z. (2001). Antimicrobial and phytochemical studies on 45. Indian medicinal plants against multi-drug resistant human pathogens. Journal of Ethnopharmocoogyl, 74, 113-123. http://dx.doi.org/10.1016/S0378-8741(00)00335-4

Ahmad, N. R., Hanit, N. L. A., \& Rashid, U. (2005). Chemical compositional and intra provenance Variation for content of essential oil in Eucalyptus crebra. Asian J. Plant Sci., 4, 519-523. http://dx.doi.org/10.3923/ajps.2005.519.523

Arunkumar, S., \& Muthuselvam, M. (2009). Analysis of Phytochemical Constituents and Antimicrobial Activities of Aloe vera L. Against Clinical Pathogens. World Journal of Agricultural Sciences, 5(5), 572-576.

Augustus, G. D. P. S., \& Seiler, G. J. (2011). Ficus elastica the Indian rubber tree an underutilized promising multi-use species. Biomass and bioenergy, 35, 7. http://dx.doi.org/10.1016/j.biombioe.2011.03.015

Beat, B., Clemens, A. J., Wright, D., Rali, T., \& Otto, S. (1990). An antimicrobial alkaloid from Ficus septica. Phytochemistry, 29(10), 3327-3330. http://dx.doi.org/10.1016/0031-9422(90)80209-Y

Bensky, D., Clavey, S., Stoger, E., \& Gamble, A. (2004). Chinese Herbal Medicine: Materia Medica (3rd ed.).

Beuchat, L. R., \& Golden, D. A. (1989). Antimicrobials occurring naturally in foods. Food Technol, 43, 134-142.

Bhuiyan, N. I., Begum, J., Nandi, N. C., \& Akter, F. (2010). Constituents of the essential oil from leaves and buds of clove (Syzigium caryophyllatum (L.) Alston) Md. African Journal of Plant Science, 4(11), 451-454

Cafarchia, C., De-Laurentis, N., Milillo, M. A., Losacco, V., \& Puccini, V. (2002). Antifungal activity of essential oils from leaves and flower of Innula viscose (Asteraceae) by Apulian region. Parasitologia, 44, 153-156.

Chang, H. W. (1995). Antibacterial effect of spices and vegetables. Food Industries, 27, 53-61.

Chavan, M. J., Shinde, D. B., \& Nirmal, S. A. (2006). Major volatile constituents of Annona squamosa L.bark. Journal of Asian natural products researches, 20, 754-757.

Cowan, M. M. (1999). Plant products as antimicrobial agents. Clinical Microbiologyl, 12, 564-582.

Daferera, D. J., Ziogas, B. N., \& Polission, M. G. (2003). The effectiveness of plant essential oils on the growth of Botrytis cinerea , Fusarium sp. and Clavibacter michiganensis subsp. michiganensis. Crop Prot, 22, 39-44. http://dx.doi.org/10.1016/S0261-2194(02)00095-9

Davis, P. H., \& Robson, M. C. (1999). Anti-inflammatory and wound healing of growth substances in Aloe vera. J. Ame. Pediatric Med. Assoc., 84, 77-81.

Du J., He, Z. D., \& Jiang, R. W. (2003). Antiviral flavonoids from the root bark of Morus alba L. Phytochemistry, 62, 1235-1238. http://dx.doi.org/10.1016/S0031-9422(02)00753-7

Durrant, W. E., \& Dong, X. (2004). Systemic acquired resistance. Annu. Rev. Phytopathol., 42, 185-209. http://dx.doi.org/10.1146/annurev.phyto.42.040803.140421

El-Nahhal, Y. (2004). Contamination and safety status of plant food in Arab countries. J. Appl. Sci., 4, 411-417. http://dx.doi.org/10.3923/jas.2004.411.417

Elsasser, B., Krohn, K., Akhtar, M. N., Florke, U., Kouam, S. F., Kuigoua, M. G., ... Kurtan, T. (2005). Revision of the absolute configuration of plumericin and isoplumericin from Plumeria rubra. Chem. Biod., 2, 99-808.

Evans, W. C. (1997). Trease and Evans pharmacognosy (14th ed.). Harcourt Brace and company. Singapore: Asia Pvt. Ltd.

Evans, W. C. (2002) Pharmacognosy: London, W.R. Saunders. 
Farias, L. R., Costa, F. T., Souza, L. A., Pelegrini, P. B., Grossi-de-Sá, M. F., Neto, S. M., ... Franco, O. L. (2007). Isolation of a novel Carica papaya $\alpha$-amylase inhibitor with deleterious activity toward Callosobruchus maculatus. Pestic. Biochem. Physiol, 87, 255-260. http://dx.doi.org/10.1016/j.pestbp.2006.08.004

Gholizadeh, A., Kumar, M., Balasubrahmanyam, A., Sharma, S., Narwal, S., Lodha, M. L., \& Kapoor, H. C. (2004). Antioxidant Activity of Antiviral Proteins from Celosia cristata. J. Plant Biochemistry \& Biotechnology, 13, 13-18. http://dx.doi.org/10.1007/BF03263184

Goyal, M., \& Mathur, R. (2011). Antimicrobial Potential and Phytochemical Analysis of Plant Extracts of Calotropis Procera., 1(3), 138-143

Gulfraz, M., Mehmood, S., Minhas, N., Jabeen, N., Kausar, R., Jabeen, K., \& Arshad, G. (2008). Composition and antimicrobial properties of essential oil of Foeniculum vulgare. African Journal of Biotechnology, 7(24), 4364-4368

Hagel, J. M., Yeung, E. C., \& Facchini, P. J. (2008). Got milk? The secret life of lacticifers. Trends. Plant Sci., 13, 631-639. http://dx.doi.org/10.1016/j.tplants.2008.09.005

Hamm, P. B., \& Hane, D. C. (1999). Effects of seedborne potato leaf roll virus on Russet Norkotah potato. Plant Dis., 83, 1122-1124. http://dx.doi.org/10.1094/PDIS.1999.83.12.1122

Hudson, J. B. (1990). Antiviral compounds from plants. Boca Raton, Florida: CRC Press.

Hull, R. (2002). Matthews' Plant Virology (4th ed.). London, UK: Academic Press.

Ikhlas, A. K., Rali, T., \& Stigher, O. (1993). Alkaloids Ficus pachyrhachis. Planta medica, 59(3), 286. http://dx.doi.org/10.1055/s-2006-959677

Ilyas, M. (1990). Flavonoids from the leaves of Ficus capensis. Ghana Journal of Chemistry, 1(3), 176-178

Iyengar, M. A. (1995). Study of Crude Drugs. Manipal Power Press, Manipal, India (8th ed.).

Jayasingh, U. (1988). Potato leaf roll virus; PLRV. Technical information bulletin 22. International Potato Center (CIP), Lima, Peru.

Juven, B. J., Kanner, J., Schved, F., \& Weisslowicz, H. (1994). Factors that interact with the antibacterial action of thyme essential oil and its active constituents. J. Appl. Bacteriol, 76, 626-631. http://dx.doi.org/10.1111/j.1365-2672.1994.tb01661.x

Kalemba, D., \& Kunicka, A. (2003). Antibacterial and antifungal properties of essential oils. Current medicinam chemistry, 10, 813-829.

Kawo, A. H., Mustapha, A., Abdullahi, B. A., Rogo, L. D., Gaiya, Z. A., \& Kumurya, A. S. (2009). Phytochemical properties and antibacterial activities of the Leaf and latex extracts of calotropis procera (ait.f.) Ait.f. Bayero Journal of Pure and Applied Sciences, 2(1), 34-40.

Kishore, G. K., \& Pande, S. (2004). Natural fungicides for management of phyto-pathogenic fungi. Annu. Rev. Plant Pathol, 3, 331-356.

Konno, K., Hirayama, C., Nakamura, M., Tateishi K., Tamura, Y., Hattori, M., \& Kohno, K. (2004). Papain protects papaya trees from herbivorous insects: role of cysteine proteases in latex. Plant J., 37, 370-378. http://dx.doi.org/10.1046/j.1365-313X.2003.01968.x

Kumon, K., Sasaki, J., Sejima, H., Takeuchi, Y., \& Hagashi, Y. (1990). Interactions between tobacco mosaic virus, pokeweed antiviral proteins and tobacco cell wall. Phytopathol., 80, 636-641. http://dx.doi.org/10.1094/Phyto-80-636

Larson, R. A. (1988). The antioxidants of higher plants. Phytochemistry, 27(4), 969-978. http://dx.doi.org/10.1016/0031-9422(88)80254-1

Mainasara, M. M., Aliero, B. L., Aliero, A. A., \& Dahiru, S. S. (2011). Phytochemical and Antibacterial Properties of Calotropis Procera (Ait) R. Br. (Sodom Apple) Fruit and Bark Extracts. International Journal of Modern Botany, 1(1), 8-11. http://dx.doi.org/10.5923/j.jimb.20110101.03

Mansour, A., Kassim, A. A. H., Salem, N., Choueiry, E., Abou-Jawdah, Y., Kalil, J., \& Aziz, N. (2008). "Virus diseases of potato" Virus Diseases of Major Crops in the Arab Region. Makkouk M.K., Fegla J.E. and Kumari G.S. Editors. Dar Nahda Al Arabia, publishers (Chapter 9, pp. 273-308).

Mantle, D., Gok, M. A., \& Lennard, T. W. (2001). Adverse and beneficial effects of plant extracts on skin and skin disorders. Adverse. Drug. React. Toxicol. Rev., 20(2), 89-103. 
Mariano, J. S. (1989). Yield losses due to potato viruses: potato leafroll virus and potato virus S. Bureau of plant Industry, Baguio City (Philippines). (Abst.). Submitted by: University Library, University of the Philippines at Los Baños, University Library (Philippines) College, Laguna 4031.

Marsh, T. L., Huffaker, R. G., Mittelhammer, R. C., Folwell, R. J., Long, G. E., Horton, D. R., \& Toba, H. H. (1998). Potato leaf roll virus net necrosis: Identifying pest management tradeoffs among inoculation interval, storage length, and tuber weight. J. of Economic Entomology, 91, 923-932.

Mazoir, N., Benharref, A., Bailén, M., Reina, M., \& Gonzalez-Coloma, A. (2008). Bioactive triterpene derivatives from latex of two Euphorbia species. Phytochemistry, 69, 1328-1338. http://dx.doi.org/10.1016/j.phytochem.2008.01.004

Mohammad, H., Sutradhar, A., Ahmad, M., \& Rnjit, K. (1991). Chemical constituents of Ficus glomerata Roxb. Journal of Bangladesh Chemical Society, 4(2), 247-250.

Moustafa, A. M., Ahmed, S. H., Nabil, Z. I., Hussein, A. A., \& Omran, M. A. (2010). Extraction and phytochemical investigation of Calotropis procera: effect of plant extracts on the activity of diverse muscles. Pharm Biol., 48(10), 1080-190. http://dx.doi.org/10.3109/13880200903490513

Mughal, S. M., \& Khalid, S. (1985). Virus diseases in relation to potato production in Pakistan. Potatoes in Pakistan, 154-165.

Murashige, T., \& Skoog, F. (1962). A revised medium for rapid growth and bioassays with tobacco tissue cultures. Physiol Plant, 15(3), 473-497. http://dx.doi.org/10.1111/j.1399-3054.1962.tb08052.x

Murugan, T. (2012). Antimicrobial Activity Of Leaves And Latex Extract Of The Herbal Plant Calotropis Gigantea (Erukku In Tamil). IJBPAS, April, 1(3), 261-270.

Nasir, E., \& Ali, S. I. (1978). Flora of Pakistan National Herbarium, Islamabad National Research Council (NRC). Nutrient requirement for Beef Cattle, 6th rev. ed. Nutrient requirement of domestic animals. Natl. Acad. Sci. Wash., 4, 421-427.

Ozcan, O., \& Sagic, M. M. L. (2006). Inhibitory effects of spice essential oils on the growth of Bacillus species. Journal of Medicinal food, 9, 418-421. http://dx.doi.org/10.1089/jmf.2006.9.418

Pandey, A. K., Rai, M. K., \& Acharya, D. (2003). Chemical composition and antimycotic activity of the essential oils of corn mint (Mentha arvensis) and lemon grass (Cymbopogon flexuosus ) against human pathogenic fungi. Pharm. Biol., 41, 421-425. http://dx.doi.org/10.1076/phbi.41.6.421.17825

Peters, D., \& Jones, R. A. C. (1981). Potato leaf roll virus. Compendium of potato diseases. In W. J. Hooker (Ed.). American Phytopathological Society, St. Paul, MN (pp. 68-70).

Pickard, W. F. (2008). Laticifers and secretory ducts: two other tube systems in plants. New Phytologist, 177, 877-888. http://dx.doi.org/10.1111/j.1469-8137.2007.02323.x

Rakib, A., Al-Ani, Saber, N. H., Diwan, Mustafa, A., \& Adhab. (2010). Efficiency of Thuja orientalis and Artimisia campestris extracts to control of Potato leaf roll virus (PLRV) in potato plants Agriculture And Biology Journal of North America.

Raphael, E. (2012). Phytochemical constituents of some leaves extract of Aloe vera and Azadirachta indica plant species. Global Advanced Research Journal of Environmental Science and Toxicology, 1(2), 014-017.

Renjie, L., Zhenhong, L., \& Shidi, S. (2010). GC-MS analysis of fennel essential oil and its effect on microbiology growth in rats’ intestine. African Journal of Microbiology Research, 4(12), 1319-1323

Ryals, J., Uknes, S., \& Ward, E. (1994). Systemic acquired resistance. Plant Physiol, 104(4), 1109-1112.

Sabry, Y., Mahmoud, M., Sanaa, M., Gad-Rab, F., Hussein, N., \& Ahmad, A. M. (2010). Antiviral Activity of Latex from Ficus nitida Against Plant Viruses. Global Journal of Biotechnology \& Biochemistry, 5(3), 198-205

Siddiqui, A. A., \& Ali, M. (1997). Practical Pharmaceutical chemistry (1st ed., pp. 126-131). New Delhi: CBS Publishers and Distributors.

Sofowora, A. (2008). Medicinal plants and traditional medicine in Africa. Ibadan: Spectrum Books Limited.

Sonboli, A., Babakhani, B., \& Mehrabian, A. R. (2006). Antimicrobial activity of six constituents of essential oil from Salvia. Zeitschrift fur Naturforschung, 61, 160-164. 
Spletzer, M. E., \& Enyedi, A. J. (1999). Salicylic acid induces resistance to Alternaria solani in hydroponically grown tomato. Phyto-pathology, 89(9), 722-727. http://dx.doi.org/10.1094/PHYTO.1999.89.9.722

Sritanyarat, W., Pearce, G., Siems, W. F., Ryan, C. A.,Wititsuwannakul, R., \& Wititsuwannakul, D. (2006). Isolation and characterization of isoinhibitors of the potato protease inhibitor I family from the latex of the rubber trees, Hevea brasiliensis. Phytochemistry, 67, 1644-1650. http://dx.doi.org/10.1016/j.phytochem.2005.12.016

Srivastava, A. K., Srivastava, S. K., \& Syamsundar, K. V. (2005). Bud and leaf essential oil composition of Syzygium aromaticum from India and Madagascar. Flavour Fragr. J., 20, 51-53. http://dx.doi.org/10.1002/ffj.1364

Staub, T. (1991). Fungicide resistance: practical experience with antiresistance strategies and the role of integrated use. Annu. Rev. Phytopathol, 29, 421-442. http://dx.doi.org/10.1146/annurev.py.29.090191.002225

Stevenson, W. R., Loria, R., Franc, G. D., \& Weingartner, D. P. (2001). Compendium of Potato Diseases. St. Paul, MN, USA: APS Press.

Taira, T., Ohdomari, A., Nakama, N., Shimoji, M., \& Ishihara, M. (2005). Characterization and antifungal activity of Gazyumaru (Ficus microcarpa) latex Chitinases: Both the chitin-binding and the antifungal activities of class I Chitinases are reinforced with increasing ionic strength. Biosci. Biotechnol. Biochem, 69, 811-818. http://dx.doi.org/10.1271/bbb.69.811

Trease, G. E., \& Evans, W. C. (1989). Pharmacognosy (13th ed., pp. 378-480). English Language Book Society, Bailliere Tindall, Britain.

Valkonen, J. P. T. (2007). Potato viruses: Economical losses and biotechnological potential. In R.Viola, C. Gebhardt, F. Govers, D. Vreugdenhil, \& D. MacKerron (Eds.), Potato biology and biotechnology (pp. 619-641). San Diego: Elsevier.

Vardar-Unlu, G., Candan, F., Sokmen, A., Daferera, D., Polissiou, M., Sokmen, M., Donmez, E., \& Tepe, B. (2003). Antimicrobial and antioxidant activity of the essential oil and methanol extracts of Thymus pectinatus Fish. Et Mey. Var. Pectinatus (Lamiaceae). Journal of Agriculture Food Chemistry, 51, 63-67. http://dx.doi.org/10.1021/jf025753e

Vlietinck, A. J., \& Berghe, D. A. (1991). Can ethnopharmacology contribute to the development of antiviral drugs? J Ethnopharmacol, 32, 141-53. http://dx.doi.org/10.1016/0378-8741(91)90112-Q

Wales, S., Platt, H. W., \& Cattlin, N. (2008). Diseases, Pests and Disorders of Potatoes (pp. 75-76). London: Manson Publishing Ltd.

Wall, J. M., Krider, M. M., Krewson, C. F., Eddy, C. R., Willaman, J. J., Corell, D. S., \& Gentry, H. S. (1954). Steroidal sapogenins VII. Survey of plants for steroidal sapogenins and other constituents. J. Am. Pharm. Ass., $63,1-7$.

Wall, M. E., Eddy, C. R., McClennan, M. L., \& Klump, M. E. (1952). Detection and estimation of steroidal sapogenins in plant tissue. Anal. Chem., 24, 1337-1341. http://dx.doi.org/10.1021/ac60068a018

Wei, F., Ma, S. C., \& Ma, L. Y. (2004). Antiviral flavonoids from the seeds of Aesculus chinensis. Journal of Natural Products, 67, 650-653. http://dx.doi.org/10.1021/np030470h

Wijesekara, R. O. B., Ratnatunga, C. M., \& Durbeck, K. (1997). The Distillation of Essential Oils. Manufacturing and Plant Construction Handbook. Protrade, Department of Foodstuffs \& Agricultural Products, Eschborn, Federal Republic of Germany.

Wititsuwannakul, D., \& Wititsuwannakul, R. (2001). Biochemistry of natural rubber and structure of latex. In T. Koyama, \& A. Steinbuchel (Eds.), Biopolymers, Polyisoprenoids (pp. 151-201). Germany: Wiley-VCH.

Yarmolinsky, L., Zaccai, M., Ben Shabat, S., Mills, D., \& Huleikel, M. (2009). Antiviral activity of ethanol extracts of Ficus binjamina and Lilium candidum in vitro. New Biotechnol, 26(6), 307-313. http://dx.doi.org/10.1016/j.nbt.2009.08.005

Zaika, L. L. (1988). Spices and herbs: their antimicrobial activity and its determination. J. of Food Safety, 9 , 97-118. http://dx.doi.org/10.1111/j.1745-4565.1988.tb00511.x 


\section{Copyrights}

Copyright for this article is retained by the author(s), with first publication rights granted to the journal.

This is an open-access article distributed under the terms and conditions of the Creative Commons Attribution license (http://creativecommons.org/licenses/by/3.0/). 